\title{
Characteristics and Nutrient Status of Two Degraded Upland Soils in Samar, Philippines
}

\author{
Victor B. Asio, Kier Lambert B. Demain, Dernie T. Olguera and \\ Leo Jude D. Villasica
}

Department of Soil Science, Visayas State University, Baybay City, Leyte

\begin{abstract}
The study evaluated the morpho-physical, chemical, and biological characteristics as well as the nutrient status of two degraded upland soils located in Sta. Rita, Western Samar and in Salcedo, Eastern Samar. Soil profiles were examined and soil erosion was determined. Composite soil and plant tissue samples were collected from different vegetation cover or crops planted by the farmers. All laboratory analyses were done following standard procedures. Results indicate that: 1) the Sta. Rita soil which is relatively younger than the Salcedo soil shows less severe degree of degradation than the Salcedo soil; 2) the nutrient status of the degraded upland soils in Sta. Rita and Salcedo are low; 3) the low nutrient status is more severe in the Salcedo soil than in the Sta. Rita soil; 4) both sites have strongly acidic soils which are low in $\mathrm{OM}$, total $\mathrm{N}$, and available $\mathrm{P}$ contents; 5) considerable variations in the soil nutrient status were observed under different vegetation covers or crops; 6) soil erosion appears to be the major soil degradation process in both degraded uplands; 7) the low nutrient concentrations in the tissues of the plants growing at the sites reflect the low nutrient status of the soils; and 8) bulk density, porosity, aggregate stability, soil $\mathrm{pH}$, organic matter, and carbon dioxide evolution appear to be good indicators of soil degradation.
\end{abstract}

Keywords: soil degradation, soil formation, shale, ultramafic rock, soil erosion 


\section{INTRODUCTION}

Soil degradation can be defined as the process which lowers the current or future capacity of the soil to produce goods or services. It is a severe global problem of modern times (Oldeman, 1994; Steiner, 2009) that greatly impacts on food security and environmental quality. Although less studied, degraded soils are widespread in upland areas throughout the country (Asio et al., 2009). Largely because of soil infertility, crop yields are low which partly explains why the poorest and most food insecure farmers are living and farming in these problematic and risk-prone lands (Roa, 2009; Steiner, 2009). Our recent study revealed that the marginal (degraded) upland soils in Inopacan, Leyte range from poorly developed on the lower slopes to well-developed on the summit slope position. The soils are highly acidic (pH close to 5.0) with low organic matter, total nitrogen and available phosphorus contents (Asio et al., 2014). Typical dominant vegetation consists of Imperata cylindrica (L.) Beauv., Saccharum spontaneum L., Melastoma malabathricum L., and Chromolaena odorata L. (Asio et al., 2014; Come et al., 2014).

To improve crop production in the marginal upland of Inopacan, Leyte, Lina et al. (2014) found that application of organic fertilizer (chicken manure) significantly improved the growth and yield of corn accompanied by an increase in soil $\mathrm{pH}$ as well as in the organic matter and total nitrogen contents of the marginal upland soil. Likewise, Ratilla et al. (2014) observed that supplementation of organic with inorganic fertilizers is necessary to enhance fertility and productivity of the marginal upland soil in Inopacan, Leyte.

Research is urgently needed to improve our understanding of the characteristics and fertility status of degraded uplands soils on Samar island; hence, this research funded by the National Research Council of the Philippines (NRCP) was conducted at two sites of varying agro-climatic conditions in Samar island to: 1) evaluate the morphological, physical, and chemical characteristics of the degraded upland soils, and 2) to assess the nutrient status of these problem soils. 


\section{MATERIALS AND METHODS}

\section{Selection of Sampling Sites}

The study was conducted in Brgy. Tulay Sta. Rita, Western Samar and in Brgy. Naparaan Salcedo, Eastern Samar (Fig. 1). The sites were selected through a preliminary survey around Samar Island. The two degraded upland sites represent two different agro-climatic zones and cropping practices (Figs. 2-3).

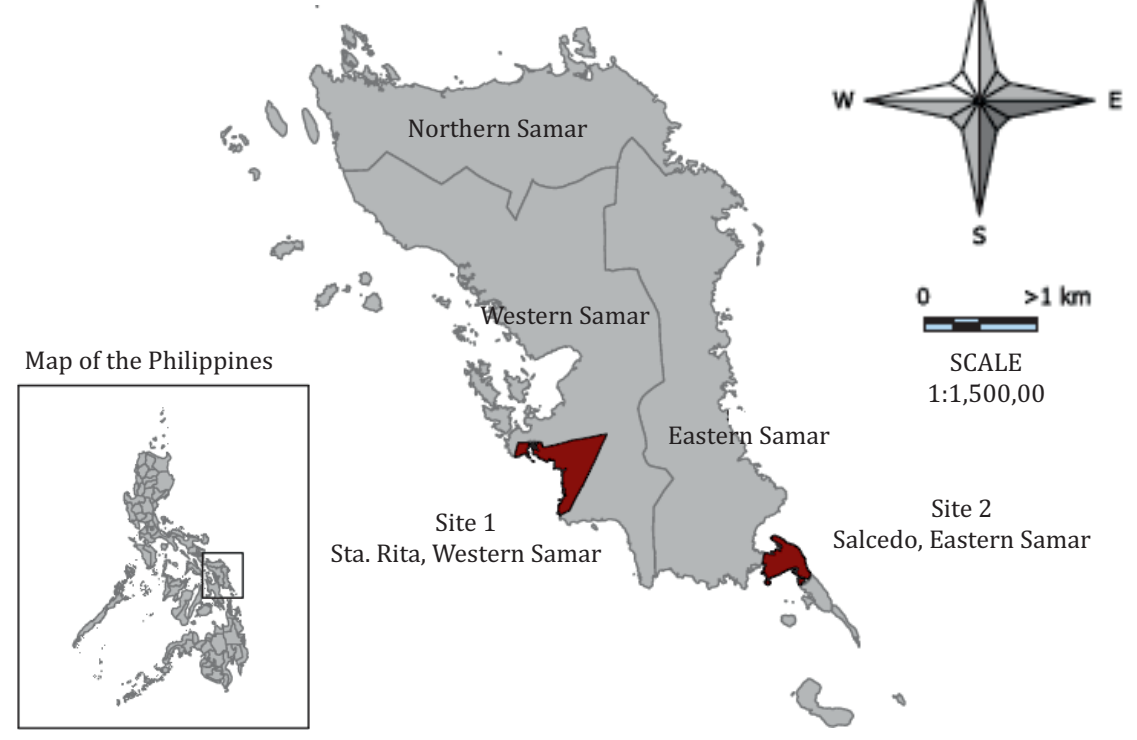

Figure 1. Location of the sampling sites in Sta. Rita, Western Samar and Salcedo, Eastern Samar.

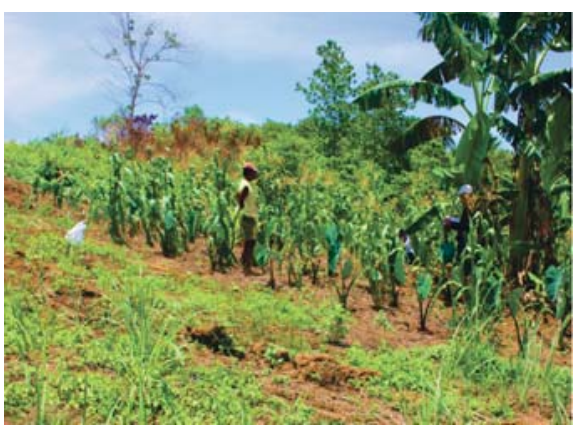

Figure 2. The Sta. Rita study site.

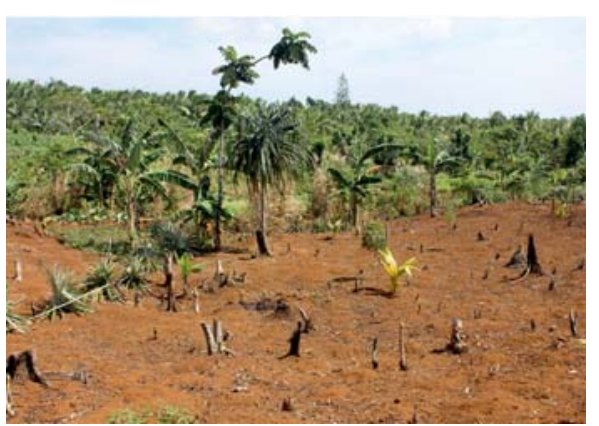

Figure 3. The Salcedo study site. 
Characteristics and Nutrient Status of Two Degraded Upland Soils in Samar

\section{Establishment of Monitoring Plots}

Four (4) soil monitoring plots, each measuring $10 \mathrm{~m} \times 10 \mathrm{~m}$, were established at each study site for soil nutrient status evaluation and monitoring. The plots were chosen based on the adjacent area approach or the space-for-time substitution approach (Asio et al, 1998). Half of each plot (i.e. $5 \mathrm{~m} \times 10 \mathrm{~m}$ ) was used for periodic soil sampling for nutrient evaluation while the other half was used for soil erosion monitoring. The plots included a control or a non-cultivated plot as basis for comparison with the farmer's field planted to different crops. They were within a 50meter distance of each other to make sure that they have the same soil type and that they are comparable in terms of soil formation.

\section{Soil and Plant Tissue Sample Collection, Preparation and Handling}

Three composite surface $(0-20 \mathrm{~cm})$ soil samples were collected every three (3) months from each plot using an Eijkelkamp soil auger. Each composite sample which came from at least five (5) sub-samples was divided into two parts. The first part was refrigerated for special analyses requiring fresh samples such as soil respiration, aggregate stability, and water holding capacity while the second part was air-dried, pulverized using a wooden mallet, and sieved in a 2-mm wire mesh to get the fine earth for the determination of most physical and chemical properties of soils. For organic matter determination, enough soil samples were further ground and allowed to pass through a $0.425-\mathrm{mm}$ wire mesh.

About 10 to 20 matured leaves of the dominant native plants and crops in the study site were collected from each monitoring plot, placed in plastic bags, and brought to the laboratory for over-drying and grinding.

\section{Soil Profile Description}

A pit measuring approximately $1 \mathrm{~m} \times 1 \mathrm{~m}$ with a depth of at least $1 \mathrm{~m}$ was dug manually in each site to examine and sample the soil profile. Soil profile description was done following the standard procedure of FAO (Jahn etal., 2006). 


\section{Soil Erosion Evaluation}

Soil erosion rate was measured using erosion metal bars that were installed in the monitoring plots (Fig. 4). Changes in height of the bar from the ground were determined periodically and the amount of eroded soil was computed using soil bulk density in the plots to arrive at soil erosion values expressed in tons/ha. In addition, the nutrient losses due to soil erosion were quantified by analyzing the nutrient contents of the eroded soils/sediments collected from the collection trough of each plot (Fig. 5).

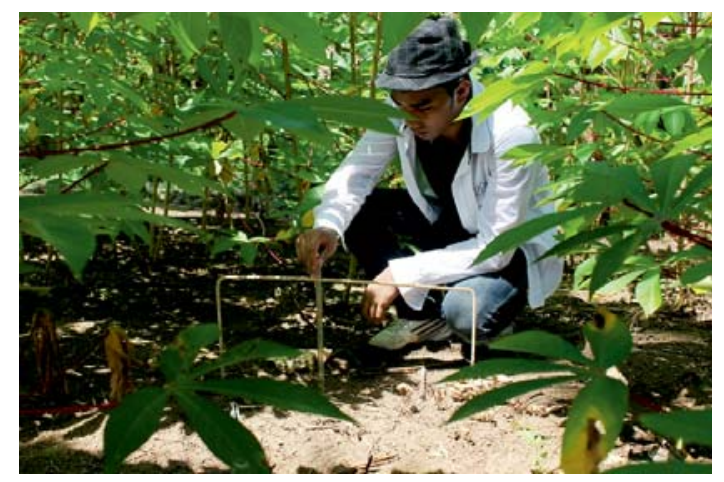

Figure 4. Monitoring of soil erosion using metal bars.

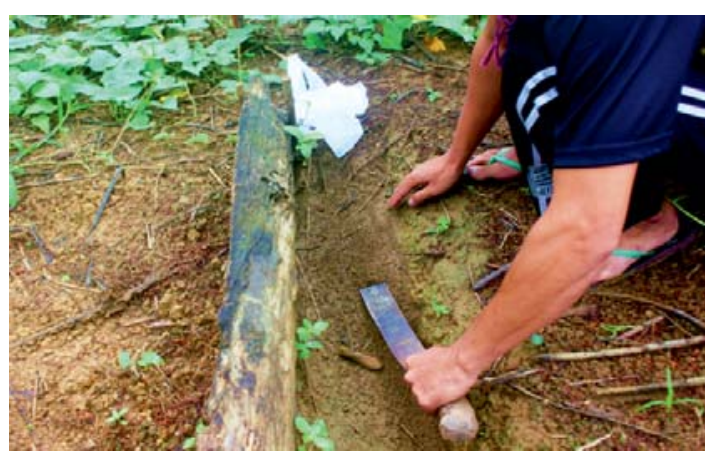

Figure 5. Collection of eroded soil trapped in the trough at the lower portion of each plot for nutrient analysis. 
Characteristics and Nutrient Status of Two Degraded Upland Soils in Samar

\section{Laboratory Analyses}

\section{Particle Size Distribution}

This was determined using the pipette method (ISRIC, 1995). Twenty grams of fine earth was treated with sodium hypochlorite ( $\mathrm{NaOCl}$ ) to destroy the organic matter. Dispersion was done by adding $10 \mathrm{~mL}$ of sodium hexametaphosphate and sonicating for three (3) min using an ultrasonic disintegrator (Hielscher UP100H). Percent silt and clay were determined by pipetting at specific time interval. The soil fractions such as sand $(2-0.02 \mathrm{~mm})$, silt $(0.02-0.002 \mathrm{~mm})$, and clay $(<0.002 \mathrm{~mm})$ were separated and computed using standard formulas.

\section{Bulk Density $\left(\mathrm{g} / \mathrm{cm}^{3}\right)$}

This was determined using the paraffin clod method (Blake and Hartge, 1986). Briefly, an undisturbed air-dry soil clod approximately $5.0 \mathrm{~cm}$ in diameter was tied securely and weighed in air. Then, the soil clod was dipped in melted (hot) paraffin. The paraffin-coated clod was weighed in air and then weighed in water. The moisture content of the clod was also determined in order to calculate the bulk density value. At least 10 clods were collected per sampling plot.

Porosity (\%)

This was calculated from the bulk density value and a constant particle density of $2.65 \mathrm{~g} / \mathrm{cm}^{3}$ using the formula:

$$
\mathrm{P}=\left(1-\frac{\rho \mathrm{b}}{\rho \mathrm{s}}\right) \times 100
$$

Where:

$$
\begin{aligned}
& \mathrm{P}=\text { porosity }(\%), \\
& \rho \mathrm{b}=\text { bulk density }\left(\mathrm{g} / \mathrm{cm}^{3}\right) \\
& \rho \mathrm{s}=\text { particle density }\left(\mathrm{g} / \mathrm{cm}^{3}\right)
\end{aligned}
$$

\section{Water Holding Capacity (\%)}

This was determined using the method of Alef and Nannipieri (2005). A $20 \mathrm{~g}$ of field moist soil was used and placed in a funnel with ordinary filter paper. Afterwards, $100 \mathrm{~g}$ of distilled water was added and was allowed to 
Asio et al.

stand overnight. Pre-weighed beakers held the percolated water and was weighed after. Percent water holding capacity was calculated using the formula:

$$
\% \mathrm{WHC}=\left(\mathrm{W}_{\mathrm{i}}-\mathrm{W}_{\mathrm{p}} / \mathrm{ODW}\right) \times 100
$$

Where:

$$
\begin{aligned}
\% \mathrm{WHC} & =\text { percent water holding capacity } \\
\mathrm{W}_{\mathrm{i}} & =\text { initial weight of the water } \\
\mathrm{W}_{\mathrm{p}} & =\text { weight of percolated water } \\
\text { ODW } & =\text { oven dry weight of soil }
\end{aligned}
$$

\section{Aggregate Stability}

This was measured following the method of Le Bissonnais (1996). Five (5) g of calibrated aggregates were immersed in a $50 \mathrm{ml}$ ethanol for 10 minutes and the ethanol was siphoned off by a pipette. The soil was transferred into an Erlenmeyer flask filled with $50 \mathrm{ml}$ distilled water and was adjusted into $200 \mathrm{ml}$. This was corked, agitated, and left for $30 \mathrm{~min}$ for sedimentation of coarse fragments and the excess water was siphoned off. The remaining mixture of soil and water was transferred to a $50 \mu \mathrm{m}$ for the measurement of fragment size distribution.

\section{Soil $p H$}

This was analyzed potentiometrically using a soil-water solution ratio of 1:2.5 (ISRIC, 1995). A 20-g fine earth soil was weighed in a plastic cup. Then $50 \mathrm{~mL}$ distilled water was added, and the solution was stirred thoroughly to form a suspension. It was allowed to stand for $30 \mathrm{~min}$ and was stirred again before reading with a pre-calibrated $\mathrm{pH}$ meter.

\section{Soil Organic Matter(\%)}

This was analyzed following the Modified Walkley-Black method (Nelson and Sommers, 1982). A $0.5 \mathrm{~g}$ soil that passed through a $0.425-\mathrm{mm}$ sieve (No. 40) was placed in a 500-mL Erlenmeyer flask. Using a volumetric pipette, the soil was added with $10 \mathrm{~mL} 1 \mathrm{~N} \mathrm{~K}_{2} \mathrm{Cr}_{2} \mathrm{O}_{7}$ and swirled gently to disperse the solution. Under the fumehood, $10 \mathrm{~mL}$ of concentrated $\mathrm{H}_{2} \mathrm{SO}_{4}$ were added rapidly and the flask was swirled immediately until the soil and reagents were mixed. The mixture was allowed to stand under the fume 
hood for $1 \mathrm{hr}$ before adding $200 \mathrm{~mL}$ of distilled water. Four (4) drops of 0phenanthroline indicator were added, into the solution, stirred using a magnetic stirrer, and titrated with $0.5 \mathrm{~N} \mathrm{FeSO}_{4} \cdot 7 \mathrm{H}_{2} \mathrm{O}$ until the solution turned into a greenish cast to dark green as endpoint.

\section{Total Nitrogen (\%)}

Total nitrogen was analyzed using the Micro-Kjeldahl method (ISRIC, 1995). A $1 \mathrm{~g}$ of the soil that passed through a $0.425-\mathrm{mm}$ sieve was added with about $1 \mathrm{~g}$ selenium mixture and $6 \mathrm{ml}$ concentrated $\mathrm{H}_{2} \mathrm{SO}_{4}$ acid and was digested using Kjeldahl digestion heaters. After which, distillation was done using Buchi distiller apparatus (50 ml 40\% $\mathrm{NaOH}$ was added); approximately $75 \mathrm{~mL}$ distillate was collected in a $125 \mathrm{ml}$ Erlenmeyer flask with $2 \% \mathrm{H}_{3} \mathrm{BO}_{3}$ and titrated with standardized $0.05 \mathrm{~N} \mathrm{H}_{2} \mathrm{SO}_{4}$ until the color changed from green to pink.

\section{Available Phosphorus (mg/kg)}

Available P was analyzed according to Bray No. 2 method (Jackson, 1958). Exactly $2.5 \mathrm{~g}$ of fine earth soil sample was weighed, added with 25 ml extracting solution $\left(0.1 \mathrm{~N} \mathrm{HCl}\right.$ and $\left.0.03 \mathrm{~N} \mathrm{NH}_{4} \mathrm{~F}\right)$, and shaken for $5 \mathrm{~min}$ using a reciprocating shaker at 180 oscillations per min. Filtrate was collected by filtering the solution through Whatman \# 42 filter paper. Two (2) $\mathrm{ml}$ aliquot of the filtrate was added with $10 \mathrm{ml}$ Reagent $\mathrm{C}$ (mixture of ascorbic acid and ammonium molybdate), mixed through the vortex mixer, and was allowed to stand for 1 hour for the blue color development (Murphy and Riley, 1962). Absorbance was read using spectrophotometer (Spectronic 20D ${ }^{+}$) at $880 \mathrm{~nm}$ wavelength.

Exchangeable Bases ( $\mathrm{Ca}, \mathrm{Mg}, \mathrm{Na}$, and $\mathrm{K})\left(\mathrm{cmol}_{c} / \mathrm{kg}\right)$

These were extracted using $1 \mathrm{~N} \mathrm{NH}_{4} \mathrm{OAc}(\mathrm{pH} 7.0$ ) method (ISRIC, 1995). Exactly $2.5 \mathrm{~g}$ soil was weighed in a $125 \mathrm{ml}$ Erlenmeyer flask and was added with $25 \mathrm{ml} 1 \mathrm{~N} \mathrm{NH}_{4} \mathrm{OAC}$ ( $\mathrm{pH} \mathrm{7.0)}$ ). The flask was covered with parafilm and was shaken for $5 \mathrm{~min}$ in a reciprocating shaker. Solutions were filtered with Whatman \# 42 in a $50 \mathrm{ml}$ beaker. The extracts were brought to the Central Analytical Services Laboratory (CASL) of VSU for the quantification of exchangeable $\mathrm{Ca}, \mathrm{Mg}, \mathrm{K}$, and $\mathrm{Na}$ with the use of an Atomic Absorption Spectrophotometer (Varian Spectra 220 FS). 
Asio et al.

\section{Carbon DioxideEvolution (Soil Respiration)}

This was determined following the closed jar method of Alef and Nannipieri (1995) which was based on the principle that as $\mathrm{CO}_{2}$ is evolved from the soil surface, it is trapped in the cylinder and is confined until it can diffuse and be absorbed by the alkali. To set-up the experiment, $100 \mathrm{~g}$ of fresh soil sample were placed in a $1 \mathrm{~L}$ jar. A separate beaker containing 15 $\mathrm{mL}$ of $1 \mathrm{~N} \mathrm{NaOH}$ as receiver for $\mathrm{CO}_{2}$ evolved was placed inside the jar. It was sealed, wrapped with carbon paper, and incubated for 1 week. After 1 week, the beaker containing the $1 \mathrm{~N} \mathrm{NaOH}$ inside the jar was treated with $1 \mathrm{ml}$ $0.05 \mathrm{~N} \mathrm{BaCl}_{2}$, added with 3 drops phenolphthalein indicator, and titrated with $1 \mathrm{~N} \mathrm{HCl}$. Appearance of white cast was the end point. Calculation of the results used the following formula:

$$
\text { C or } \mathrm{CO}_{2} \text { evolved }\left(\mathrm{mg} \mathrm{kg}^{-1} \text { week }{ }^{-1}\right)=(\mathrm{B}-\mathrm{V}) \mathrm{NE}
$$

Where:

$$
\begin{aligned}
\mathrm{B}= & \text { volume }(\mathrm{mL}) \text { of acid needed to titrate the } \mathrm{NaOH} \text { in } \\
& \text { the jars from the control cylinders to the endpoint (control } \\
& \text { cylinder contain all the reagents except soilsample) } \\
\mathrm{V}= & \text { volume }(\mathrm{mL}) \text { of acid needed to titrate the } \mathrm{NaOH} \text { in } \\
& \text { the jars exposed to the soil atmosphere to the endpoint } \\
\mathrm{N}= & \text { normality of the acid } \\
\mathrm{E}= & \text { equivalent weight }
\end{aligned}
$$

\section{RESULTS AND DISCUSSION}

\section{Site and Soil Profile Characteristics}

The study sites are degraded uplands which differ from each other in terms of climate, geology, soil, and cropping systems (FAO, 1978).

Sta. Rita Site. Sta. Rita is a $3^{\text {rd }}$ class municipality in Western Samar. Its major economic activity is agriculture although low crop productivity is a major problem. The site in Brgy. Tulay is located on the backslope of a sedimentary hill at an elevation of $30 \mathrm{~m}$ above sea level (asl). Uncultivated portions of the area are generally covered with cogon (Imperata cylindrica (L.) Beauv.) and talahib (Saccharum spontaneum L.) grasses as well as Melastoma malabathricum L. while the cultivated portions are planted with crops such as sweetpotato (Ipomoea batatas (L.) Lam.), cassava (Manihot esculenta Crantz), gabi (Colocasia esculenta (L.) Schott), vegetables like squash (Cucurbita maxima Duchesne) and string beans 
(Phaseolus vulgaris L.) and banana (Musa sapientum L.). The study was conducted on a farmer's field and thus, considered the cropping system of the farmer. According to the Modified Coronas Climate Classification, Sta. Rita has a Type IV climate where rainfall is more or less evenly distributed throughout the year with an average annual rainfall of 2,545 mm. This climate type resembles the second type more closely since it has no dry season.

The degraded soil which formed from shale parent rock is a welldeveloped soil possessing an Ap-AB-Bt-C horizonation (Fig. 6; Table 1). It is dark yellowish brown silty clay on the surface and yellowish brown silty clay in the subsurface. The soil is slightly plastic and slightly sticky. In terms of chemical properties, the Sta Rita soil is strongly acidic and contains low amounts of organic matter, total $\mathrm{N}$, and available P. It is classified as a Hapludult which indicates that it is a strongly weathered soil but relatively younger than the Salcedo soil. It also shows less severe degree of soil degradation than the Salcedo soil. PCARRD (1987) reported that the Sta. Rita soil has a mixed clay mineralogy consisting of montmorillonite, vermiculite, and kaolinite.

\section{Soil Profile Description}

\section{Sta. Rita, Western Samar}
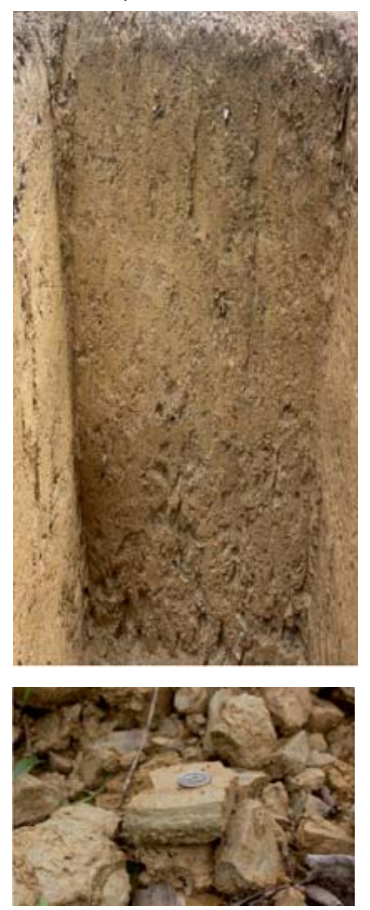

0-10 cm; dark yellowish brown (10 YR 3/4); silty clay; Ap sub-angular blocky structure; friable, plastic, sticky; few medium roots; few fine pores; clear smooth boundary.

10-24 cm; yellowish brown (10 YR 5/6); silty clay; sub-

$\mathrm{AB}$ angular blocky; firm, slightly sticky, slightly plastic; very few fine roots; few medium pores; clear smooth boundary.

24-44 cm; yellowish brown (10 YR 5/6); silty clay; subBt angular blocky; firm, plastic and sticky; very few very fine roots; very few fine pores; clear smooth boundary.

44-59 cm; dark yellowish brown (10 YR 4/6); sandy

C clay; sub-angular blocky; firm, slightly sticky, slightly plastic; very few very fine roots and pores; clear smooth boundary; few rock fragments.

$59 \mathrm{~cm}$ and below; dark yellowish brown (10 YR 4/6);

$\mathrm{R}$ consolidated shale rock which is generally easily broken by shovel. 
Salcedo site. Salcedo is a $4^{\text {th }}$ class municipality in the southern portion of Eastern Samar. Income per capita is extremely low due to the low agricultural productivity. The site in Brgy. Naparaan is situated on the summit of an ultramafic hill at an elevation of $50 \mathrm{~m}$ asl. The upland farm is alternately planted to cassava (Manihot esculenta Crantz) and sweetpotato (Ipomoea batatas (L.) Lam.) although banana (Musa sapientum L.) is also found. Cogon grass (Imperata cylindrica (L.) Beauv.) is dominant in uncultivated portions of the area. It has a Type II climate characterized by no dry season but with a very pronounced maximum rain period from December to February. This climate type has no single dry month and has the minimum monthly rainfall from March to May. The Department of Agriculture (DA) Region VIII (www. darfu8.tripod.com) reported that Salcedo has an average annual rainfall of 3,146.6 $\mathrm{mm}$ which is much higher than that of the Sta. Rita site.

Fig. 7 and Table 1 present the profile characteristics of the degraded Salcedo soil developed from peridotite rock (ultramafic rock). The soil is yellowish red with loam texture on the surface which becomes reddish brown clay in the subsurface. It is plastic and sticky when wet but friable when moist. In terms of chemistry, the soil is strongly acidic and contains very low amounts of organic matter, nitrogen, and available phosphorus. The soil is dominated by kaolinite, hematite, and gibbsite clay minerals (Navarrete et al., 2007). It is classified as Hapludox which suggests that it is a highly weathered soil, low in plant nutrients, and rich in $\mathrm{Al}$ and Fe oxides.

\section{Soil Physical Properties as Influenced by Vegetation Cover}

\section{Particle Size Distribution}

Table 2 presents the particle size distribution of the soils in the different plots at the two study sites. For Sta. Rita, the soil under natural grass vegetation has higher clay content than those planted to the crops. This is probably the effect of soil erosion which is more severe in the cultivated plots. 


\section{Soil Profile Description}

Salcedo, Eastern Samar

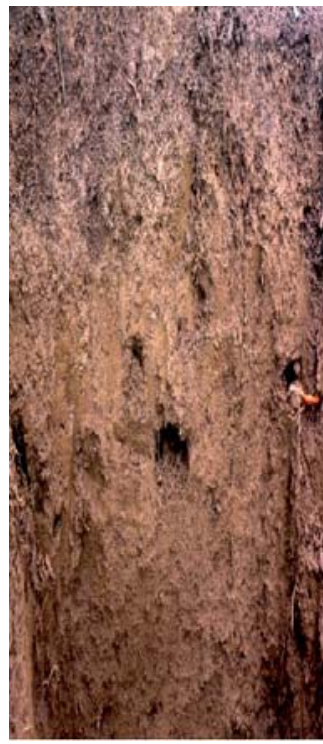

Ap

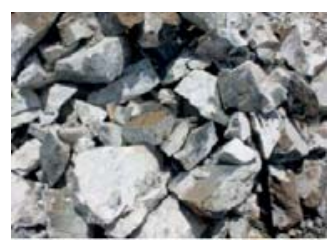

Figure 7. Morphological characteristics of Salcedo Soil
0-10 cm; yellowish red (5 YR 4/6); loam; sub-angular blocky structure; friable, plastic and sticky; few medium roots; few fine pores; clear smooth boundary.

10-28 cm; yellowish red (5 YR 4/6); sandy clay loam; Bt sub-angular blocky structure; friable, plastic and sticky; very few fine roots; few medium pores; clear smooth boundary.

28-48 cm; yellowish red (5 YR 4/6); silty clay; subBox1 angular blocky structure; friable, plastic and sticky; very few very fine roots; very few fine roots; clear smooth boundary.

48-70 cm; reddish brown (7.5 YR 4/4); clay; subBox2 angular blocky structure; friable, plastic and sticky; very few very fine root and pores; clear smooth boundary; few rock fragments.

$70 \mathrm{~cm}$ below; reddish brown (7.5 YR 4/4); clay; Box3 subangular blocky structure; firm, slightly sticky, slightly plastic; no roots; very few very fine pores; abrupt smooth boundary; many rock fragments.

Bedrock compared of ultramafic rock (peridotite)

\section{Aggregate Stability}

Aggregate stability is defined as the resistance of soil aggregates to the disintegrating influence of water and mechanical manipulation (Jury and Horton, 2004). In principle, stable aggregates are less prone to erosion but this is true only for macroaggregates since they are large and heavy. The data in Table 3 were determined according to the method of Le Bissonnais (1996). 
Table 1. Chemical properties and particle size distribution of the degraded soils in Sta. Rita, Samar and Salcedo, Eastern Samar.

\begin{tabular}{|c|c|c|c|c|c|c|c|c|c|c|c|c|c|}
\hline \multirow{2}{*}{ Site } & \multirow{2}{*}{ Horizon } & \multirow{2}{*}{$\begin{array}{l}\text { Depth } \\
(\mathrm{cm})\end{array}$} & \multirow{2}{*}{$\mathrm{pH}\left(\mathrm{H}_{2} \mathrm{O}\right)$} & \multirow{2}{*}{$\mathrm{OM}(\%)$} & \multirow{2}{*}{$\begin{array}{l}\text { Total } \\
\text { N (\%) }\end{array}$} & \multirow{2}{*}{$\begin{array}{c}\text { Available } \\
\mathrm{P} \\
(\mathrm{mg} / \mathrm{kg}) \\
\end{array}$} & \multicolumn{4}{|c|}{$\begin{array}{c}\text { Exchangeable Bases } \\
\left(\mathrm{cmol}_{\mathrm{c}} / \mathrm{kg}\right)\end{array}$} & \multicolumn{3}{|c|}{ Particle Size Analysis (\%) } \\
\hline & & & & & & & $\mathrm{K}$ & $\mathrm{Na}$ & $\mathrm{Mg}$ & $\mathrm{Ca}$ & Sand & Silt & Clay \\
\hline \multirow{5}{*}{ Sta. Rita, W. Samar } & Ap & $0-10$ & 4.15 & 0.83 & 0.04 & 6.89 & 0.33 & 0.06 & 2.56 & 4.40 & 30.15 & 39.81 & 30.04 \\
\hline & $A B$ & $10-24$ & 3.75 & 0.75 & 0.03 & 0.25 & 0.24 & 0.11 & 2.68 & 4.94 & 35.59 & 39.72 & 24.68 \\
\hline & $\mathrm{Bt}$ & $24-44$ & 4.07 & 0.81 & 0.04 & 0.00 & 0.73 & 0.11 & 2.82 & 6.34 & 26.32 & 31.78 & 41.90 \\
\hline & $\mathrm{C}$ & $44-59$ & 3.98 & 0.80 & 0.04 & 0.00 & 0.37 & 0.15 & 2.80 & 6.59 & 35.32 & 39.89 & 24.79 \\
\hline & $\mathrm{R}$ & 59-Down & 4.01 & 0.80 & n.d. & 0.00 & 0.30 & 0.16 & 2.88 & 8.42 & n.d. & n.d. & n.d. \\
\hline \multirow[t]{5}{*}{ Salcedo, E. Samar } & Ap & $0-10$ & 4.28 & 0.86 & 0.04 & 0.00 & 0.30 & 0.12 & 2.92 & 12.07 & 30.66 & 37.49 & 31.85 \\
\hline & $\mathrm{Bt}$ & $10-28$ & 4.36 & 0.87 & 0.04 & 0.00 & 0.32 & 0.13 & 2.92 & 16.38 & 33.18 & 42.70 & 24.12 \\
\hline & Box1 & $28-48$ & 4.28 & 0.86 & 0.03 & 0.00 & 0.43 & 0.20 & 2.93 & 15.49 & 25.57 & 76.85 & 42.42 \\
\hline & Box2 & $48-70$ & 4.38 & 0.88 & 0.05 & 0.00 & 0.40 & 0.26 & 2.92 & 12.81 & 29.50 & 30.23 & 40.27 \\
\hline & Box3 & 70-Down & 4.71 & 0.94 & 0.05 & 0.00 & 0.48 & 0.14 & 2.89 & 13.91 & 57.05 & 16.60 & 26.35 \\
\hline
\end{tabular}

Table 2. Particle size distribution of the degraded soils in Sta. Rita, Western Samar and Salcedo, Eastern Samar under different vegetation cover.

\begin{tabular}{cccc}
\hline Site & Vegetation & \multicolumn{2}{c}{ Particle Size Distribution (\%) } \\
\cline { 2 - 4 } & Natural Vegetation & $37.95 \pm 3.75$ & $22.5 \pm 1.25$ \\
Sta. Rita, W. & Sweetpotato & $32.95 \pm 1.25$ & $40 \pm 2.50$ \\
Samar & Gabi & $30.45 \pm 2.50$ & $42.5 \pm 2.50$ \\
& Cassava & $27.95 \pm 1.25$ & $47.5 \pm 2.50$ \\
\hline Salcedo, E. & Natural Vegetation & $35.45 \pm 3.75$ & $22.5 \pm 5.00$ \\
Samar & Grassland (Cogon) & $17.95 \pm 5.00$ & $37.5 \pm 0.00$ \\
& Upper Cassava & $22.95 \pm 2.50$ & $35 \pm 1.25$ \\
& Lower Cassava & $12.95 \pm 0.00$ & $35 \pm 0.05$ \\
\end{tabular}

\pm values are standard error. Lower and upper cassava indicate position of plots in the site 
Characteristics and Nutrient Status of Two Degraded Upland Soils in Samar

Table 3. Aggregate stability of the degraded soils in Sta. Rita, Western Samar and Salcedo, Eastern Samar under different vegetation cover.

\begin{tabular}{ccccc}
\hline \multirow{2}{*}{ Site } & Vegetation & $\begin{array}{c}\text { Mean Weight } \\
\text { Diameter } \\
(\mathrm{mm})\end{array}$ & $\begin{array}{c}\text { Aggregate } \\
\text { Stability }\end{array}$ & Crustability \\
\hline Sta. Rita & Natural Vegetation & $1.6 \pm 0.05$ & Stable & Rare \\
& Sweetpotato & $1.0 \pm 0.05$ & Medium & Moderate \\
& Gabi & $1.1 \pm 0.04$ & Medium & Moderate \\
\hline Salcedo & Cassava & $1.3 \pm 0.03$ & Medium & Moderate \\
& Grassland (Cogon) & $1.7 \pm 0.03$ & Stable & Rare \\
& Upper Cassava & $1.6 \pm 0.06$ & Stable & Rare \\
& Lower Cassava & $1.8 \pm 0.02$ & Stable & Rare \\
\hline
\end{tabular}

\pm values are standard errors. Lower \& upper cassava indicate position of plots in the site.

For the Sta. Rita site, the natural grass vegetation showed more stable soil aggregates than the other plots planted to agricultural crops. It is clear that cultivation has already caused physical soil degradation. For the Salcedo site, all the plots showed stable aggregates which means that cultivation has not influenced the aggregate stability. In the above method, crustability is given more emphasis since crusting that results from erosion can decrease the soil permeability to water. When this happens, surface run-off is increased resulting in higher soil erosion rate.

Interestingly, the two selected degraded uplands vary in aggregate stability probably due to the differences in cementing agent. Sta. Rita soil is mainly cemented by organic matter and some amount of iron oxides which explains the stability of the soil under the natural vegetation compared to the other crops. On the other hand, Salcedo soil has high amount of iron oxides (Navarrete et al., 2007) which is a very stable cementing agent of soil particles.

\section{Bulk Density}

Bulk density is the mass per unit bulk volume of undisturbed soil, expressed in $\mathrm{g} / \mathrm{cm}^{3}$. It is used as an index of compaction and porosity and directly affects root development and gas movement in the soil. Table 4 reveals the bulk density under various vegetation cover at the two study sites. The soil under the natural grass vegetation has lower bulk density values than the plots planted to crops. This reflects the increased soil compaction as a result of cultivation. 
Asio et al.

\section{Porosity}

Porosity is an index of the relative pore volume in the soil (Jahn et al., 2006). Tan (2005) suggested that it is the total amount of pore spaces or that portion of soil volume not occupied by solid particles, but occupied by air and water.

Table 4 shows the percent porosity of the soils at both Sta. Rita and Salcedo sites. As can be seen, there is a decreasing trend in the porosity of the soil from the natural vegetation plots to the cassava and sweetpotato plots. This result is related to the trend in bulk density values. Soil disturbance due to farm operation and increased organic matter decomposition explains the decreased porosity in the plots planted to crops. This result suggests that porosity is also a good indicator of physical soil degradation.

\section{Water Holding Capacity}

Water holding capacity (WHC) refers to the ability of soils to hold a specific volume of water. It is directly related to the porosity and indirectly related to the bulk density. Furthermore, it is mainly influenced by the soil texture as it takes the pore volume to be filled and holds a certain water volume.

Table 4 presents the WHC of the soils in the study sites. There is no clear trend for both sites probably because water holding capacity is strongly influenced by soil texture which is a stable property. Thus, water holding capacity is not a good indicator of soil degradation.

Table 4. Bulk density, porosity, and water holding capacity of the degraded soils in Sta. Rita, Western Samar and Salcedo, Eastern Samar under different vegetation cover.

\begin{tabular}{llcc}
\hline \multicolumn{1}{c}{ Site } & $\begin{array}{c}\text { Bulk } \\
\text { Density } \\
\left(\mathrm{g} / \mathrm{cm}^{3}\right)\end{array}$ & Porosity (\%) & $\begin{array}{c}\text { Waterholding Capacity } \\
(\%)\end{array}$ \\
\hline $\begin{array}{l}\text { Sta. Rita, W. Samar } \\
\text { Natural Vegetation }\end{array}$ & $1.25 \pm 0.03$ & $52.83 \pm 2.23$ & $58.65 \pm 2.76$ \\
Sweetpotato & $1.53 \pm 0.05$ & $42.14 \pm 2.22$ & $60.78 \pm 3.70$ \\
Grassland & $1.57 \pm 0.05$ & $40.67 \pm 2.13$ & $62.90 \pm 1.68$ \\
Cassava & $1.48 \pm 0.05$ & $43.19 \pm 1.60$ & $61.60 \pm 1.80$ \\
\hline Salcedo, E. Samar & & & \\
Natural Vegetation & $1.32 \pm 0.03$ & $49.06 \pm 1.57$ & $44.17 \pm 1.40$ \\
Sweetpotato & $1.35 \pm 0.05$ & $49.06 \pm 3.00$ & $47.14 \pm 1.13$ \\
Cassava in upper stage & $1.61 \pm 0.04$ & $39.41 \pm 2.09$ & $51.59 \pm 3.07$ \\
Cassava in lower stage & $1.66 \pm 0.03$ & $37.32 \pm 3.30$ & $49.24 \pm 2.98$ \\
\hline
\end{tabular}

Values are the mean of 3 determinations (Aug 2012, Nov 2012 and Feb 2013) \pm values indicate standard error 
Characteristics and Nutrient Status of Two Degraded Upland Soils in Samar

Soil Chemical Properties as Influenced by Vegetation Cover

Soil $p H$

Table 5 presents the $\mathrm{pH}$ values of the soils at both Sta. Rita and Salcedo sites. Soil pH values in Sta. Rita range from 4.68 to 5.61 while for the Salcedo site they range from 5.15 to 6.01 . The data reveal a decreasing trend from the natural grass vegetation plots to the plots planted with agronomic crops. The data suggest that an acidification occurs with crop cultivation which can be expected due to the losses of nutrients as a result of crop removal. The results indicate that soil $\mathrm{pH}$ can be an indicator of chemical soil degradation.

\section{Soil Organic Matter}

Organic matter refers to all decomposed, partly decomposed, and undecomposed materials of plant and animal origin (Jahn et al., 2006). It is the critical component of soil that enables it to carry out necessary environmental function though supplying plant nutrients and facilitating soil aggregation (Martin etal.,2006). Table 5 shows the organic matter content of the soils in the plots having different vegetation in Sta. Rita. As can be seen, there is a decrease from the natural vegetation plot to the plots planted with crops. In contrast, no clear trend can be observed in the Salcedo site indicating that cultivation has not caused a decline in the organic matter content of the soil probably because the farmers are applying organic fertilizer (chicken manure).

\section{Total Nitrogen}

Nitrogen is one of the essential elements acquired by plants in ionic form $\mathrm{NO}_{3}{ }^{-}$and $\mathrm{NH}_{4}^{+}$. It is mainly deficient in the tropics since it undergoes various losses such as leaching and volatilization. Table 5 presents the total nitrogen of the soils as influenced by vegetation cover in the two sites. No clear trend can be observed in terms of the effects of the vegetation and cropping system. This agrees with the data on the organic matter content since it is the major source of $\mathrm{N}$ in the soil. 
Asio et al.

\section{Available Phosphorus}

Table 5 shows the soil available phosphorus in the Sta. Rita site. Cassava and the natural vegetation contain slightly higher amount of available $\mathrm{P}$ than the other plots planted to gabi and sweetpotato. For the Salcedo site, there is high variability of the available $\mathrm{P}$ values between plots. This may be due to the effect of the high chicken dung application by the farmers.

\section{Exchangeable Bases}

Exchangeable bases $(\mathrm{K}, \mathrm{Na}, \mathrm{Ca}$ and $\mathrm{Mg}$ ) regulate the $\mathrm{pH}$ of the soil and thus are an important factor of soil fertility. They may also reflect the contribution of parent material and the influence of soil management practices.

For the Sta. Rita site, no clear differences can be observed between the different plots except the soil under cassava which shows the lowest exchangeable $\mathrm{K}$ (Table 5). This is probably because this crop requires high amount of potassium for the development of its roots. For the Salcedo site, the natural vegetation plot tends to have higher exchangeable bases compared to the cassava plots. This suggests a decline in the exchangeable bases as a result of cultivation.

\section{Soil Biological Property}

Biological degradation refers to the deterioration of the dynamic soil biological system through alteration in microbial substantial output and decreasing its population which is mainly attributed to the fluctuation of the general condition of the landscape (Nannipieri et al., 2003). Kirk et al. (2004) suggested that carbon dioxide evolution is related to the amount of carbon in the soil. The higher the value, the more microorganisms are present in the soil and the more diverse are the microbial decomposers indicating an increased fertility of the landscape.

Table 6 shows the carbon dioxide evolved from soils collected from the two study sites. Natural grass vegetation in Sta Rita shows some low $\mathrm{CO}_{2}$ values but none in the Salcedo soil. This supports the other data collected pointing to more severe degree of degradation of the Salcedo soil. Very low $\mathrm{CO}_{2}$ values can be observed in some sweetpotato and cassava plots which also indicate very low microbial activity. Nannipieri et al. (2003) explains the importance of microorganisms in the soil ecosystem by rejuvenating nutrient s through proficient biogeochemical cycling. 
Table 5. Soil chemical properties of the degraded soils in Sta. Rita, Western Samar and Salcedo, Eastern Samar under different vegetation cover.

\begin{tabular}{|c|c|c|c|c|c|c|c|c|}
\hline \multirow[t]{2}{*}{ Site } & \multirow[t]{2}{*}{$\mathrm{pH}\left(\mathrm{H}_{2} 0\right)$} & \multirow[t]{2}{*}{$\mathrm{OM}(\%)$} & \multirow{2}{*}{$\begin{array}{l}\text { Total } \\
\mathrm{N}(\%)\end{array}$} & \multirow{2}{*}{$\begin{array}{l}\text { Available } \\
\text { P (mg/kg) }\end{array}$} & \multicolumn{4}{|c|}{ Exchangeable Bases $\left(\mathrm{cmol}_{\mathrm{c}} / \mathrm{kg}\right)$} \\
\hline & & & & & $\mathrm{K}$ & $\mathrm{Na}$ & $\mathrm{Ca}$ & $\mathrm{Mg}$ \\
\hline \multicolumn{9}{|c|}{ Sta. Rita, W. Samar } \\
\hline $\begin{array}{l}\text { Natural } \\
\text { Vegetation }\end{array}$ & $5.43 \pm 0.03$ & $4.27 \pm 0.11$ & $0.28 \pm 0.03$ & $6.58 \pm 0.68$ & $0.74 \pm 0.16$ & $0.06 \pm 0.02$ & $5.39 \pm 0.28$ & $6.04 \pm 0.09$ \\
\hline Sweetpotato & $5.23 \pm 0.09$ & $4.83 \pm 0.32$ & $0.36 \pm 0.03$ & $8.79 \pm 0.65$ & $1.09 \pm 0.52$ & $0.05 \pm 0.02$ & $4.95 \pm 0.07$ & $6.15 \pm 0.05$ \\
\hline Gabi & $5.24 \pm 0.03$ & $3.11 \pm 0.12$ & $0.25 \pm 0.03$ & $5.37 \pm 0.28$ & $1.37 \pm 0.62$ & $0.03 \pm 0.01$ & $4.36 \pm 0.06$ & $5.45 \pm 0.21$ \\
\hline Cassava & $5.06 \pm 0.20$ & $3.79 \pm 0.06$ & $0.35 \pm 0.02$ & $5.70 \pm 0.68$ & $0.29 \pm 0.19$ & $0.05 \pm 0.01$ & $4.99 \pm 0.06$ & $6.05 \pm 0.05$ \\
\hline \multicolumn{9}{|l|}{ Salcedo, E. Samar } \\
\hline Natural & & & & & & & & \\
\hline Vegetation & $5.63 \pm 0.13$ & $4.98 \pm 0.08$ & $0.24 \pm 0.03$ & $2.83 \pm 1.25$ & $0.26 \pm 0.03$ & $0.03 \pm 0.01$ & $2.44 \pm 0.25$ & $0.73 \pm 0.04$ \\
\hline Sweetpotato & $5.44 \pm 0.12$ & $4.69 \pm 0.32$ & $0.24 \pm 0.02$ & $4.67 \pm 0.59$ & $0.22 \pm 0.04$ & $0.03 \pm 0.01$ & $1.71 \pm 0.22$ & $0.41 \pm 0.03$ \\
\hline $\begin{array}{r}\text { Cassava in } \\
\text { upper } \\
\text { slope }\end{array}$ & $5.34 \pm 0.13$ & $5.75 \pm 0.12$ & $0.28 \pm 0.03$ & $4.89 \pm 1.85$ & $0.21 \pm 0.02$ & $0.04 \pm 0.01$ & $1.12 \pm 0.08$ & $0.33 \pm 0.03$ \\
\hline $\begin{array}{c}\text { Cassava in } \\
\text { lower } \\
\text { slope }\end{array}$ & $5.40 \pm 0.10$ & $4.75 \pm 0.06$ & $0.25 \pm 0.02$ & $0.83 \pm 0.40$ & $0.17 \pm 0.02$ & $0.03 \pm 0.01$ & $1.40 \pm 0.07$ & $0.36 \pm 0.02$ \\
\hline
\end{tabular}

Values are the mean of 3 determinations (Aug 2012, Nov 2012 and Feb 2013)

\pm values indicate standard error 
Table 6. Carbon dioxide evolution of the degraded soils in Sta. Rita, Western Samar and Salcedo, E. Samar under different vegetation cover.

\begin{tabular}{cccc}
\hline \multirow{2}{*}{ Site } & \multicolumn{3}{c}{$\mathrm{CO}_{2}$ Evolution $(\mathrm{mg} / \mathrm{kg} /$ week) } \\
\cline { 2 - 4 } & Aug-12 & Oct-12 & Feb-13 \\
\hline Sta. Rita, W. Samar & 0.23 & 0.02 & 0.05 \\
Natural Vegetation & 0.01 & 0.01 & 0.00 \\
Sweetpotato & 0.01 & 0.00 & 0.00 \\
Gabi & 0.00 & 0.00 & 0.00 \\
Cassava & & & \\
Natural Vegetation & 0.00 & 0.00 & 0.00 \\
Sweetpotato & 0.01 & 0.00 & 0.00 \\
Cassava-upper slope & 0.00 & 0.01 & 0.03 \\
Cassava-lower slope & 0.01 & 0.01 & 0.05 \\
\hline Salcedo, E. Samar & & &
\end{tabular}

\section{Soil Erosion}

Soil erosion is the physical removal of topsoil by various agents including falling raindrops, run-off, through the soil profile, wind velocity and even the action of gravity (Lal, 1990). Soil erosion rate was measured using metal erosion bars installed in the monitoring plots. The amount of eroded soil was calculated from the difference in the height of the metal bar from the soil surface. Like any other method of soil erosion measurement, the data obtained from the metal bar method may be difficult to interpret and may not truly reflect the actual soil erosion rate of an area.

Fig. 8 reveals the soil erosion rates under different crops in Sta. Rita. It shows that cassava resulted in the highest erosion rate compared to sweetpotato and gabi. The soil disturbance due to weeding and other farm operations led to the higher erosion rates.

Fig. 9 shows the erosion rate in Salcedo as influenced by vegetation cover. The grassland vegetation has lower soil erosion rate compared to cassava. This clearly shows the influence of the vegetation cover in protecting the soil against erosion. Comparing the two sites, the Salcedo site shows higher erosion rate than the Sta. Rita site. 


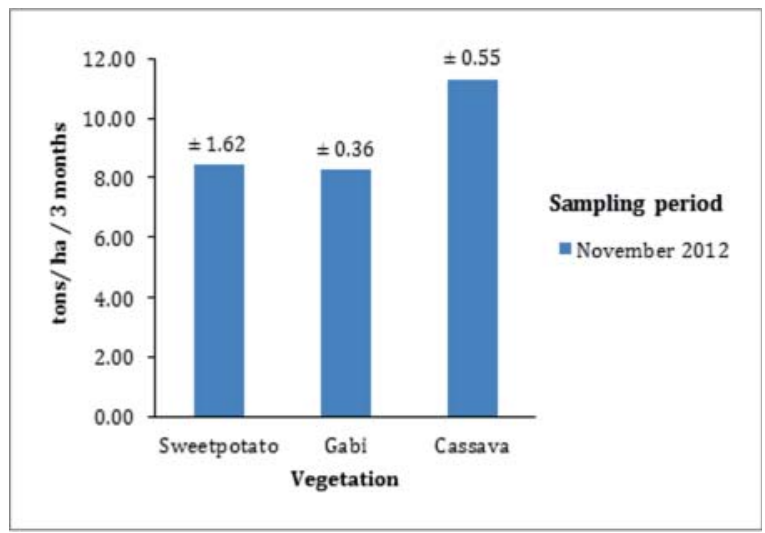

Figure 8. Soil erosion rate under different vegetation covers in Sta. Rita, Western Samar. \pm values indicate standard error.

This can be partly explained by the much higher rainfall in the latter.

Fig. 10 reveals the nutrient content of the eroded soil collected from the Sta. Rita site showing that the eroded soils contain considerable amounts of organic matter (OM), P, and exchangeable bases. The data also show that the nutrient contents of the eroded soil differ slightly with the crop planted.

The considerable amount of $P$ contained in the eroded soil is difficult to explain considering the degraded nature of the soil. This may indicate that the farmer has probably applied fertilizers to his crops. A slightly different trend can be seen from Figure 11 for the eroded soil from the Salcedo site. The eroded soils contain high amount of organic matter as well as significant amounts of $\mathrm{P}$ and exchangeable bases which could have come from the chicken manure that is regularly applied by the farmers. These results support the widely held view that the loss of nutrients through soil erosion contributes to the soil degradation.

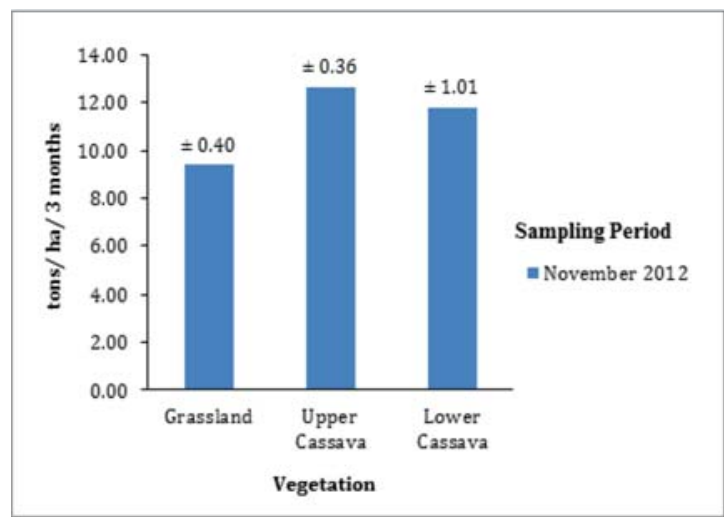

Figure 9. Soil erosion rate under different vegetation cover in Salcedo, Eastern Samar. \pm values indicate standard error. 


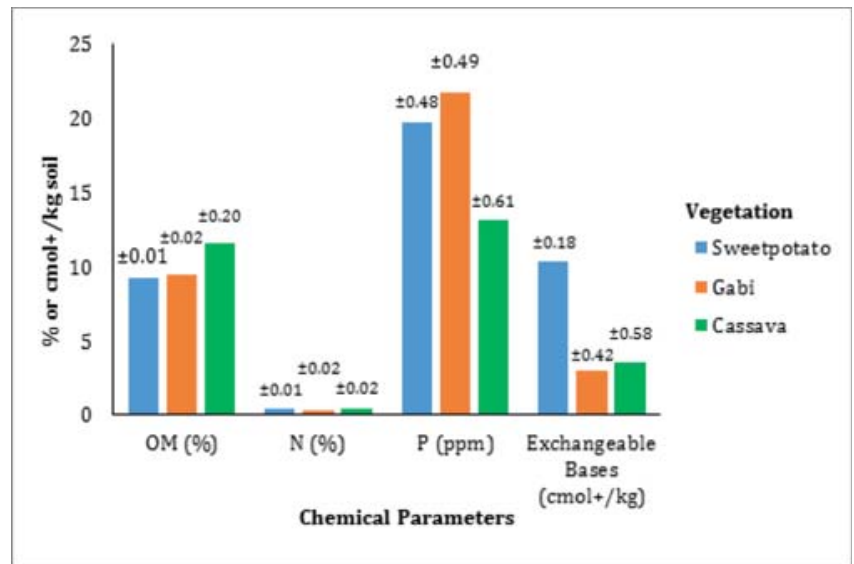

Figure 10. Nutrient content of the eroded soils in Sta. Rita, Western Samar at different vegetation cover. \pm values indicate standard error.

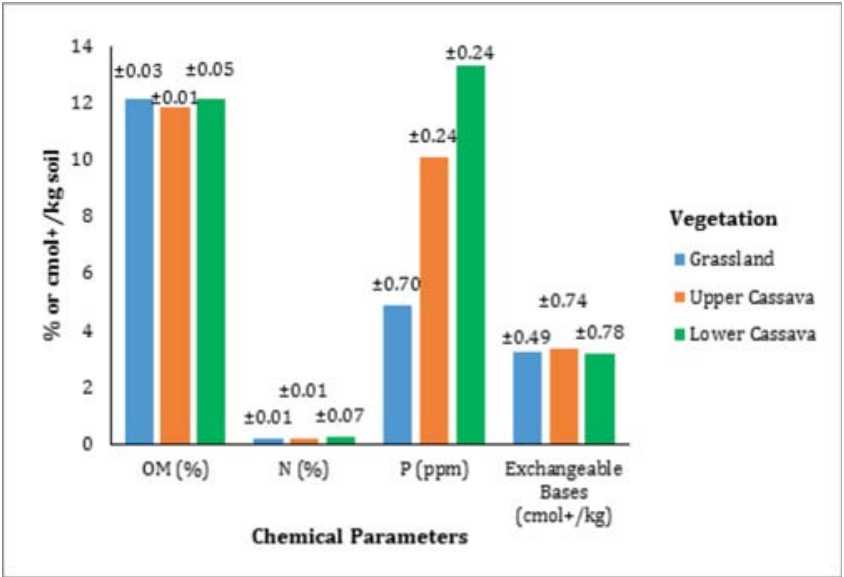

Figure 11. Nutrient content of the eroded soils in Salcedo, Eastern Samar at different vegetation cover. \pm values indicate standard error.

\section{Plant Tissue Nutrient Concentration}

Leaf samples of dominant plant species inside the sampling plots were taken and their nutrient concentrations were analyzed. The leaf nutrient concentrations generally reflect the nutrient status of the plant and to a lesser extent the amount of available nutrients in the soil. It is now widely recognized that $\mathrm{N}$ and $\mathrm{K}$ are needed by plants in larger amounts Table 7 shows the amounts of these nutrients in the dominant plant species growing at the two sites. All are below the normal nutrient concentrations required for plant growth and development (Marschner, 1995). In 
Characteristics and Nutrient Status of Two Degraded Upland Soils in Samar

particular, the level of phosphorus is extremely low. These data clearly reflect the low nutrient status of the soils and imply that nutrient addition is necessary for good crop yield.

Table 7. Leaf concentrations of N, P, K, and Ca of the dominant plant species in Sta. Rita and Salcedo sites.

\begin{tabular}{|c|c|c|c|c|c|c|}
\hline \multirow[b]{2}{*}{ Site } & \multirow[b]{2}{*}{ Plots } & \multirow[b]{2}{*}{$\begin{array}{c}\text { Dominant } \\
\text { plant }\end{array}$} & \multicolumn{4}{|c|}{$\%$ Nutrient } \\
\hline & & & $\mathrm{N}$ & $\mathrm{P}$ & K & $\mathrm{Ca}$ \\
\hline Ultisol & Natural vegetation & Talahib & 0.238 & 0.006 & 1.314 & 0.198 \\
\hline (Sta. Rita, & Sweetpotato & Sweetpotato & 1.131 & 0.011 & 1.338 & 0.743 \\
\hline Western & Gabi & Gabi & 0.957 & 0.011 & 1.337 & 0.762 \\
\hline Samar) & Cassava & Cassava & 1.342 & 0.007 & 1.328 & 0.547 \\
\hline $\begin{array}{c}\text { Oxisol } \\
\text { (Salcedo }\end{array}$ & Natural vegetation & Cogon & 1.315 & 0.009 & 1.365 & 1.141 \\
\hline Eastern & Cassava1 & Cassava & 1.210 & 0.007 & 1.208 & 0.369 \\
\hline Samar) & Cassava2 & Cassava & 0.779 & 0.011 & 1.318 & 0.781 \\
\hline
\end{tabular}

\section{CONCLUSIONS}

Based on the results, the following conclusions may be drawn:

1. The nutrient status of the degraded uplands in Sta. Rita and Salcedo are low. In general, the low nutrient status is more severe in the Salcedo site than in the Sta. Rita site which is related to the more weathered nature of the former than the latter. The differences in rainfall and parent material between the two soils partly explain the above results.

2. Both sites have strongly acidic soils which are low in OM, total N, available $\mathrm{P}$, and exchangeable bases contents. The low nutrient status of the soils is reflected by the low leaf concentration of the nutrients (N, P, K, Ca).

3. Considerable variations in the soil nutrient status were observed under different vegetation covers or crops planted.

4. Soil erosion is the major soil degradation process in the degraded uplands studied. Soil erosion resulted not only in considerable soil losses but nutrients losses as well.

5. Soil erosion varied with vegetation cover and site. It was much higher under the agronomic crops than under the natural vegetation. In addition, soil erosion was higher in the Salcedo site than in the Sta. Rita site which is related to climatic and soil characteristics.

6. Bulk density, porosity, aggregate stability, soil pH, organic matter, and carbon dioxide evolution are good indicators of soil degradation.

7. The low nutrient concentrations in the tissues of plants growing at the two sites reflect the low nutrient status of the soils. 
Asio et al.

\section{ACKNOWLEDGMENT}

This research was funded by the National Research Council of the Philippines (NRCP) project no. F-146 "Characteristics and nutrient status of degraded upland soils in Samar Island". I am grateful to Dr. Cecilia P. Reyes (former Executive Director), Dr. Portia G. Lapitan (former NRCP Division VI Chair), Ms. Cecilia J. Baquireza (Supervising Research Specialist), Ma. Josefina B. Marin (Administrative Officer) and Ms. Leilani C. Domingo-Pelegrina (former Senior Science Research Specialist) for their approval and assistance in many ways.

I am also thankful to my Science Aide (Kier Lambert Demain) and my undergraduate thesis advisees (Dernie Olguera and Leo Jude Villasica) whose enthusiasm and hard work contributed greatly to the success of the project. Prof. Jovino L. Padullo Jr. of ESSU-Salcedo assisted us during our sampling in Salcedo.

\section{REFERENCES}

ALEF K. and P. NANNIPIERI (eds.). 1995. Methods in Applied Soil Microbiology and Biochemistry. Academic Press, London.

ASIO V. B., R. JAHN, K. STAHR, and J. MARGRAF. 1998. Soils of the tropical forest of Leyte, Philippines: impact of different land uses on status of organic matter and nutrient availability. In: Soils of Tropical Forest Ecosystems (A. Schulte and D. Ruhiyat, eds). Springer Verlag, BerlinHeidelberg-New York. pp. 38 - 44

ASIO V. B., R. JAHN, F.O. PEREZ, I.A. NAVARRETE, and S.M. ABIT Jr. 2009.A review of soil degradation in the Philippines. Annals of Tropical Research.31(2):69-94.

ASIO V.B., S.B. LINA, D.S. MARANGUIT, A.B. BOLLEDO, R.J.T. DOGUILES, C.M.O. QUINONES, J.R. SABIJON and K.L.B. DEMAIN. 2014. Characteristics of soils in the marginal uplands of Inopacan, Leyte. Annals of Tropical Research 36 (Supplement): 1-15.

BLAKE, G.R. and K.H. HARTGE. 1986. Methods of soil analysis, Part 1. American Society of Agronomy-Soil Science Society of America, 677 South Segoe Road, Madison. 
Characteristics and Nutrient Status of Two Degraded Upland Soils in Samar

COME R.S., M.M. BANDE, M. CAMUTUHAN, M.J.B. ALIP and R. PORAZO. 2014. Biomass and carbon stocks of vegetation in the marginal uplands in Inopacan, Leyte. Annals of Tropical Research 36 (Supplement): 7081.

FOOD AND AGRICULTURE ORGANIZATION OF THE UNITED NATIONS (FAO). 1978. Soil map of the Samar Island. Philippines. FAO, Rome.

INTERNATIONAL SOIL REFERENCE AND INFORMATION CENTER (ISRIC). 1995. Procedures for soil analysis (L.P. Van Reuwijk, Editor). Wageningen, the Netherlands.

JACKSON, M.L. 1958. Soil Chemical Analysis. Prentice-Hall, Inc., New Jersey.

JAHN R., H.P. BLUME, V.B. ASIO, and P. SCHAD. 2006. Guidelines for Soil Description ( $4^{\text {th }}$ ed.). FAO, Rome.

JURY W. A. and R. HORTON. 2004. Soil Physics (6 ${ }^{\text {th }}$ ed.). John Wiley and Sons. Hoboken, New Jersey.

LAL, R. 1990. Soil Erosion in the Tropics, Principles and Management. McGraw-Hill, Inc., USA.

LE BISSONNAIS. 1996. Aggregate stability and Assessment of Soil Crustability and Erodibility: I. Theory and Methodology. European Journal of Soil Science. 47: 425-437.

LINA S.B., D.S. MARANGUIT, V.B. ASIO, J.R. SABIJON, K.L.B. DEMAIN and A.B. BOLLEDO. 2014. Growth performance of corn as influenced by the combined application of organic and inorganic fertilizers in a marginal upland soil. Annals of Tropical Research 36 (Supplement): 16-29.

MARSCHNER H. 1995. Mineral Nutrition of Higher Plants. (2 ${ }^{\text {nd }}$ ed.). Academic Press, London.

NANNIPIERI P., J. ASHER, M.T. CECCHERINI, L. LANDI, G. PIETRAMELLARA and G. RANELLA. 2003. Microbial diversity and soil functions. European J. Soil Science. 54: 655-670. 
NAVARRETE I.A., V.B. ASIO, R. JAHN and K. TSUTSUKI. 2007. Characteristics and genesis of two strongly weathered soils in Samar, Philippines: Australian Journal of Soil Research 45: 153-163

NELSON, D.W. and L.E SOMMERS. 1982. Methods of soil analysis, Part 2. American Society of Agronomy-Soil Science Society of America, 677 South Segoe Road, Madison.

OLDEMAN L.R. 1994. Global extent of soil degradation. In: Oldeman LR (ed) Soil resilience and sustainable use. CAB International, UK.

OLSEN S.R. and L.E. SOMMERS. 1982. Methods of soil analysis, Part 1. American Society of Agronomy-Soil Science Society of America, 677 South Segoe Road, Madison.

PCARRD. 1987. Soil Taxonomy: Key to effective land use. Book series No. 51. Proc. Int. Forum on Soil Taxonomy and Agrotechnology Transfer. PCARRD, Los Baños, Laguna.

RATILLA B.C., S.P. TOLEDO and O.B. CAPUNO. 2014. Evaluation of organicbased fertilizer for corn production in the marginal uplands of Inopacan, Leyte. Annals of Tropical Research 36 (Supplement): 107123.

ROA J.R. 2007. Food insecurity in fragile lands: Philippine cases through the livelihood lens. PhD Dissertation, Wageningen.

STEINER K.G. 1996. Causes of soil degradation and development approaches to sustainable soil management. MargrafVerlag, Weikersheim. 